\title{
Pesticides and the evolution of the genetic structure of Anopheles coluzzii populations in some localities in Benin (West Africa)
}

Arsène Jacques Y. H. Fassinou 1,3* , Come Z. Koukpo ${ }^{1,3}$, Razaki A. Ossè ${ }^{1,4}$, Fiacre R. Agossa ${ }^{1}$, Roseric Azondékon ${ }^{1}$, André Sominahouin', Casimir Kpanou 1,3, Hermann Sagbohan 1,3, Boulais Yovogan ${ }^{1}$, Martin C. Akogbéto ${ }^{1,2}$ and Michel Sezonlin ${ }^{1,2}$

\begin{abstract}
Background: Changes in the natural habitats of insect groups are determined the genetic polymorphisms between individuals. The objective of this study was to establish the genetic structure of the Anopheles coluzzii populations in four localities of Benin.

Methods: Insecticide surveys and larval sampling were conducted on 4 study localities, including Cotonou, Ketou, Zagnanado, and Sô-Ava. Molecular characterizations were performed on the Anopheles mosquitoes collected with the allelic and genotypic frequencies of $k d r$ gene determined. The multiple comparison Chi square test for proportions was performed with $\mathrm{R}$ version 3.3.3. Next, the observed heterozygosity, expected heterozygosity, and indices of fixation, and genetic differentiation were estimated. Finally, the Hardy-Weinberg equilibrium (EHW) was determined to assess whether panmixia exists in the different populations of mosquitoes of the agroecological zones under study.

Results: Carbamates, pyrethroids, organophosphorus and organochlorines use have been reported in all localities except Sô-Ava. Anopheles coluzzii was strongly represented across all study localities. The L1014F allele was observed in the localities of Kétou, Cotonou and Zagnanado. Likewise, insecticide selection pressure of homozygous resistant individuals (L1014F/L1014F) was significantly higher in Kétou, Cotonou and Zagnanado ( $p$ value $<0.05$ ). Surprisingly in Sô-Ava, a relatively high frequency of the $L 1014 \mathrm{~F}$ allele despite the reported absence of pesticide use was observed. All mosquito populations were found to be deficient in heterozygosity across the study sites $\left(F_{15}<0\right)$. No genetic differentiation $\left(F_{S T}<0\right)$ was observed in the localities of Zagnanado and Kétou.

Conclusion: The survey on the use of insecticides showed that insecticide selection pressures differ across the investigated localities. It would be desirable to rotate or apply formulations of combined products with different modes of action. Doing so would enable a better management of resistant homozygous individuals, and mitigate the resistance effect of commonly used insecticides.
\end{abstract}

Keywords: Anopheles coluzzii, Genetic structure, Pesticide, Malaria, Resistance, Benin

\section{Background}

Vector-borne diseases are among the main causes of morbidity and mortality in humans and animals [1]. Out of the many vector-borne human pathologies, malaria

\footnotetext{
*Correspondence: arsenf88@yahoo.fr

${ }^{1}$ Centre de Recherche Entomologique de Cotonou (CREC), Cotonou, Benin

Full list of author information is available at the end of the article
}

stands out as it remains a major public health problem worldwide, with over 219 million cases estimated in 2017 [2]. In 2017, 15 of the 91 countries that reported cases of malaria, have also reported $80 \%$ malaria transmission rate. Unfortunately, these nations are mostly in sub-Saharan Africa, with the exception of India [2].

In the fight against malaria, two prevention methods are used: long-lasting insecticidal nets (LLINs) and indoor residual spraying (IRS) [3]. On the African

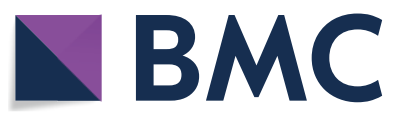

(c) The Author(s) 2019. This article is distributed under the terms of the Creative Commons Attribution 4.0 International License (http://creativecommons.org/licenses/by/4.0/), which permits unrestricted use, distribution, and reproduction in any medium, provided you give appropriate credit to the original author(s) and the source, provide a link to the Creative Commons license, and indicate if changes were made. The Creative Commons Public Domain Dedication waiver (http://creativecommons.org/ publicdomain/zero/1.0/) applies to the data made available in this article, unless otherwise stated. 
continent, the use of pyrethroid-based insecticides in malaria control has increased considerably in recent years after series of LLINs and indoor spraying campaigns [4]. Materials impregnated with insecticide have proven relative effectiveness in almost all epidemiological profiles [5, 6].

In developing countries, urbanization and agriculture are factors that can contribute to population growth and, consequently, to the increase of malaria transmission rates [7]. Urbanization can increase malaria transmission following a poor implementation of the sanitation plan. For example, a lack of adequate water drainage system and an excessive distortion of the natural terrain due to human dwellings and community infrastructure may promote the emergence of mosquito breeding sites that are suitable environments for the reproduction of malaria vectors, the emergence of adult mosquitoes and subsequently promote human-vector contact [8]. Based on the soils, agricultural fields are also very good breeding sites for malaria vectors as they contribute to the selection of resistant individuals due to the uncontrolled use of multiple pesticides [9]. Malaria vector insects are able to develop multiple mechanisms of resistance to insecticides depending on their exposure to agricultural pollutants [10]. In the Republic of Benin, several studies have confirmed the role of pesticides in the development of insecticide resistance in An. gambiae [11, 12]. Insecticide resistance is, therefore, not a new phenomenon in this region. In 1999, it was reported that the main malaria vector, An. gambiae sensu stricto (s.s.) had already developed resistance to synthetic pyrethroids in Benin [13]. The massive use of insecticides in agriculture [14] and in public health $[15,16]$ is the main driver of the development of insecticide resistance in malaria vectors [17]. To this day, two main mechanisms are known to be involved in metabolic resistance to insecticides in mosquitoes. The mutations on the voltage-gated sodium channel gene that are the targets of pyrethroids, and the overproduction of detoxifying enzymes are the main mechanisms of mosquito resistance to insecticide [18-20].

Dispersion of point mutations in Vgsc gene in anopheline populations and other taxa that are phylogenetically close has been associated with the use of pyrethroids, which are the most commonly used against malaria vectors in the world [21].In sub-Saharan Africa, this mutation affects the $k d r$ gene site $L 1014$ leading to a synonymous substitution of leucine to phenylalanine (L1014F) [21] on one side or leucine to serine (L1014S) [17] on the other.

Genetic polymorphism, a characteristic of living organisms, and gene flow between individuals of different populations can be caused in observed changes in the natural habitats of insect groups [22]. According to those studies, spatial variations may be linked, for example, to the splitting of an insular environment [22], to the particularities of some biotopes, such as cellars, ponds [23], or to strict infeodation to certain hosts [24]. Temporal variations in the availability of habitat resources, on the other hand, may affect the structure of the populations by influencing seasonal changes in numbers that occur through migration [25]. Ecology and demography are not to be ignored as they are key factors in the process of species distribution. Knowledge of the genetic structure of disease vector populations is essential to understanding vector capacity through the identification of the underlying factors and, by extension, to better assess the effectiveness of vector control programmes, as well as the implementation of new control strategies when needed [26, 27].

The main goal of this study was to establish the genetic structure of the populations of An. coluzzii collected from different agro-ecological zones in Benin. Specifically, to (i) gather an inventory of the different pesticides used in those zones; (ii) establish the genetic structure of An. coluzzii populations, and (iii) study the genetic and genotypic differentiations.

\section{Methods \\ Study area}

This study was conducted in the Republic of Benin, a West African country, located in the intertropical zone between the equator and the tropic of cancer, specifically the $6^{\circ} 30^{\prime}$ and $12^{\circ} 30^{\prime}$ parallels of North latitude on one hand and, and the meridians $1^{\circ}$ and $3^{\circ} 40^{\prime}$ of eastern longitude, one the other hand. Based on pedoclimate factors and the diversity of crops grown in some localities, Benin is divided into eight agro-ecological zones [28]: the extreme north Benin, the Northern cotton zone, the South Borgou Food Zone, the Western Atacora Zone, the Center Cotton Zone, the Bar Land Zone, the Fishing Zone, and the Depression zone.

Mosquitoes used as biological material in this study were collected from the localities of Kétou (Cotton Zone of Center), Zagnanado (Bar Land Zone), Cotonou and Sô-Ava in the Fishing Zone. Figure 1 shows the study locations represented by many mosquito collections sites.

All prospected collection sites are located in southern Benin regardless of the zone. A diversity of agricultural practices is observed in the municipalities of Cotonou, Kétou and Zagnanado. In these localities, producers use pesticides to maximize their agricultural yield. Since the community of Sô-Ava is largely a lake region, the main activity practiced by residents is fishing in various forms with various gear. A survey of agricultural practices in the study localities identified the different families of insecticide used. 


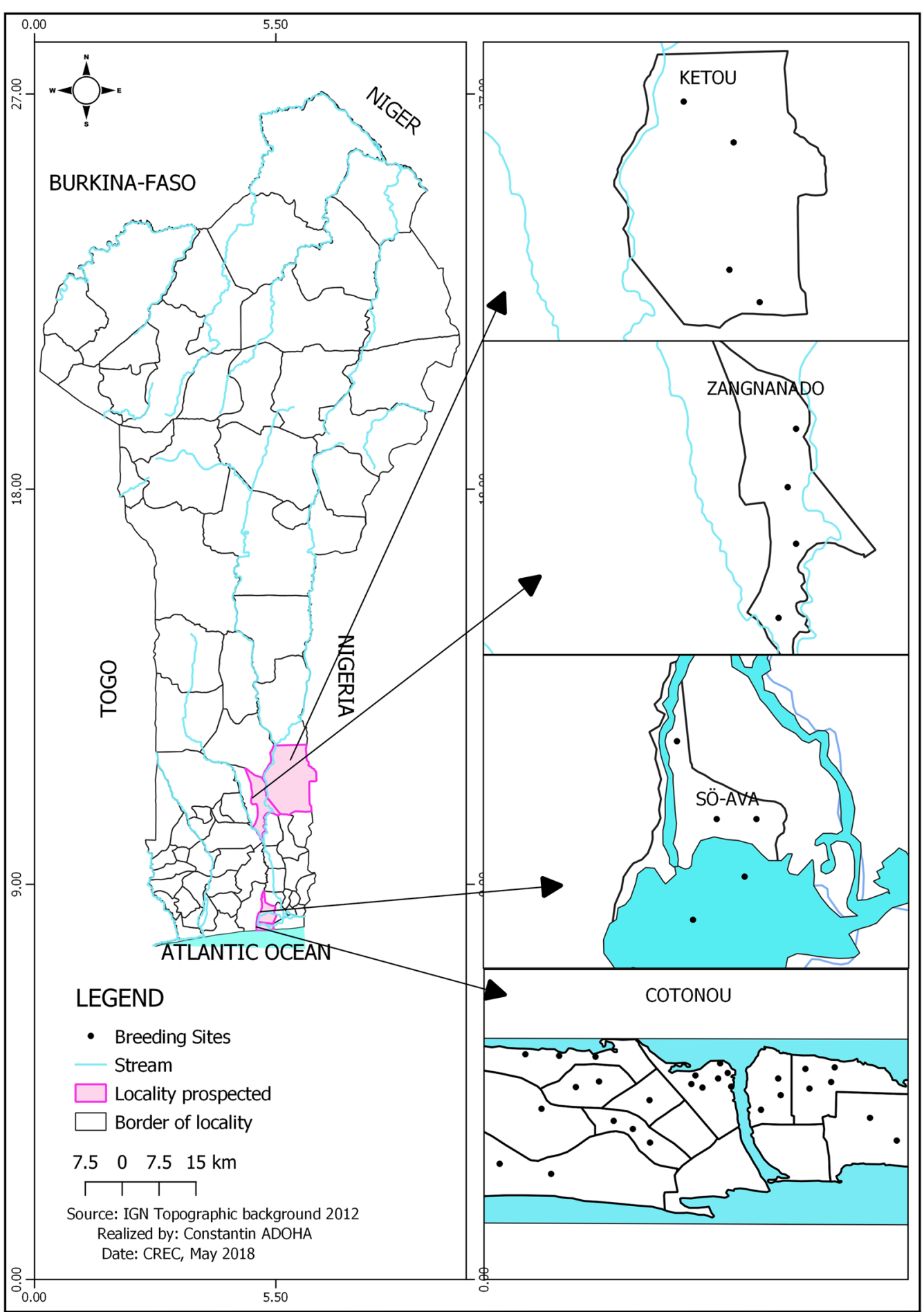

Fig. 1 Map showing the different study localities

\section{Insecticide use survey}

Surveys of the use of different insecticides used by farmers were carried out in the four study localities (Cotonou,
Sô-Ava, Kétou, Zagnanado). The numbers of farmers available in each locality was determined using the second-generation communal development plan and the 
village notebooks of the departments of each locality. The number of farmers in Cotonou, Sô-Ava, Zagnanado and Kétou are approximately 10,864, 52,279, 34303 and 103,694, respectively [29-32]. The farmers were chosen according to a reasoned choice technique: in the different farming populations, children and women were not questioned because they are usually responsible for subsistence farming which does not require the use of pesticides. The remaining group consisted of large producers of cotton, cereals, tubers and market gardening products. The various crops grown and the number of farmers, survey respondents by municipality are recorded in Table 1.

Farmers have been found to grow a variety of products whose dominance varied from a municipality to another (Table 1). The frequency of use and the pesticide types used to improve yield depended on the culture and financial means available to each farmer. These factors limited the scope of this study as it was difficult to estimate the frequency of pesticide use.

\section{Mosquito sample collection}

Anopheles larvae were collected from May 2015 to October 2017 during dry and rainy seasons in the localities initially selected using the "dipping" technique [33]. It consists of taking the mosquito larvae from the surface of the breeding site using a ladle. The harvested larvae of An. gambiae sensu lato (s.l.) were filtered and poured into different containers before being transported to the Insectarium of the "Centre de Recherche Entomologique de Cotonou" (CREC) for rearing. As reported in the entomological literature $[34,35]$, between 80 and 300 eggs are laid by the female Anopheles on the surface of the water. After the aquatic life cycle, emerging adult mosquitoes inherit common genetic traits from their parents with whom they share a very similar genetic profile. These individuals will later lay their eggs as adults in the same or surrounding breeding sites of the same locality with a high consanguinity. For this reason and in order to achieve a better appreciation of the genetic diversity of the populations, a few individuals from the breeding sites were randomly sampled in order to replicate, in the

Table 1 Distribution of survey respondents by municipality

\begin{tabular}{llrlll}
\hline Municipality & \multicolumn{4}{l}{ Type of farmers } \\
\cline { 2 - 6 } & $\begin{array}{l}\text { Cotton } \\
\text { producers }\end{array}$ & $\begin{array}{r}\text { Vegetable } \\
\text { producers }\end{array}$ & $\begin{array}{l}\text { Tubercule } \\
\text { producers }\end{array}$ & $\begin{array}{l}\text { Cereal } \\
\text { producers }\end{array}$ & Total \\
\hline Cotonou & & 49 & 3 & 8 & 60 \\
Kétou & 34 & 5 & 6 & 15 & 60 \\
Zagnanado & 25 & 5 & 6 & 24 & 60 \\
Sô-Ava & & 47 & 10 & 13 & 60 \\
Total & 59 & 106 & 25 & 50 & 240 \\
\hline
\end{tabular}

extent possible, the genetic structure that better reflects that of the underlying population from which the collected mosquitoes originate from.

The black dots in Fig. 1 indicate the different mosquito breeding sited prospected in each municipality. The samples collected at each site were grouped to form the population of each commune. Adult mosquitoes emerging from the reared larvae were stored in plastic tubes (Eppendorf $1.5 \mathrm{ml}$ ) at $-20{ }^{\circ} \mathrm{C}$ for subsequent molecular analysis.

\section{Molecular characterization of the collected mosquito samples DNA extraction}

Whole mosquitoes were crushed in $200 \mu \mathrm{l}$ of $2 \%$ CTAB (20 g of cetyl trimethyl ammonium bromide; $100 \mathrm{ml}$ Tris (Tris hydro methyl aminomethane) $\mathrm{HCl} 1 \mathrm{M} ; 20 \mathrm{ml}$ of EDTA (Ethylene acid tetraacetic diamine) $0.5 \mathrm{M}$ and $81.8 \mathrm{~g}$ of $\mathrm{NaCl}$ completed at $1 \mathrm{l}$ with bi-distilled water). After $5 \mathrm{~min}$ in a water bath at $65{ }^{\circ} \mathrm{C}$, the mash was then mixed with $200 \mu \mathrm{l}$ of chloroform, and centrifuged at 12,000 revolutions per minute for $5 \mathrm{~min}$. The resulting supernatant was delicately recovered in another tube and supplemented by $200 \mu \mathrm{l}$ of isopropanol, thoroughly mixed by inversion then again, centrifuged at 12,000 revolutions per minute for $15 \mathrm{~min}$. The liquid contained in the tube was carefully disposed of to preserve the pellet at the bottom of the tube. Next, $200 \mu \mathrm{l}$ of $70 \%$ ethanol were added to this pellet for precipitation. After $5 \mathrm{~min}$ at 12,000 revolutions of centrifugation, the supernatant of the tube was again finely reversed. The pellet was then drained for at least $3 \mathrm{~h}$ on the bench. The extracted DNA was reconstituted with $20 \mu \mathrm{l}$ of sterile water and left in suspension on the bench all night long.

\section{Identification of the different species of Anopheles gambiae collected}

The strong morphological similarity between the species of the An. gambiae complex is the source of confusion during the identification of the constituent taxa. To overcome this difficulty, it is necessary to supplement morphological studies with molecular analysis [36]. The PCR diagnostic approach was reportedly used to identify mosquito species in multiple studies. It is based on the characteristic and irreversible insertion of a transposable element of $230 \mathrm{pb}$ (SINE200) on the X chromosome of An. coluzzii (form M), while it is absent in its twin An. gambiae (form S). This genetic hereditary feature allows unambiguous, simple and direct recognition of the molecular forms still called $\mathrm{M}$ and S [36].

The PCR protocol used includes an initial denaturation of the DNA material at $94{ }^{\circ} \mathrm{C}$ for $5 \mathrm{~min}$ followed by 35 
cycles. Each cycle includes a denaturation phase at $94{ }^{\circ} \mathrm{C}$ for $30 \mathrm{~s}$, a primer hybridization at $54{ }^{\circ} \mathrm{C}$ for $30 \mathrm{~s}$, and an elongation phase through sequential nucleotide additions at $72{ }^{\circ} \mathrm{C}$ for $30 \mathrm{~s}$. At the end of all cycles, a final elongation phase at $72{ }^{\circ} \mathrm{C}$ for $10 \mathrm{~min}$ is conducted to allow a total amplification of the sequences in progress. In addition to the conventional components of a chain polymerization reaction, the primers 200X6.1F TCG CCT TAG ACC TTG CGT TA and 200X6.1R CGC TTC AAG AAT TCG AGA TAC were used [36]. The amplification product obtained are stored at a final temperature of $4{ }^{\circ} \mathrm{C}$ before being migrated on a $1.5 \%$ agarose gel in the presence of ethidium bromide used as an intercalant and migration front. Figure 2, developed by Santolamazza et al. [36], illustrates the characteristic electrophoretic profile of each species.

The protocol of Santolamazza et al. [36] does not allow to differentiate Anopheles quadriannulatus, Anopheles melas and An. gambiae species because their electrophoretic profile shows bands that are similar at the same level, thus with almost the same molecular weight and by extension the same size. Since samplings were not done from lagoon coastal environments, it is logical to exclude from the analyzed samples, the existence of $A n$. melas, a brackish-infeoded species. All mosquitoes were processed for molecular species identification using the Santolamazza et al. PCR protocol. All pre-identified mosquitoes were processed to a second PCR using the protocol of Scott et al. [37] to confirm the absence of other species from An. gambiae s.l. The protocol consists in determining the polymorphisms in the intergenic spacer (IGS) of ribosomal DNA. It allows the identification of

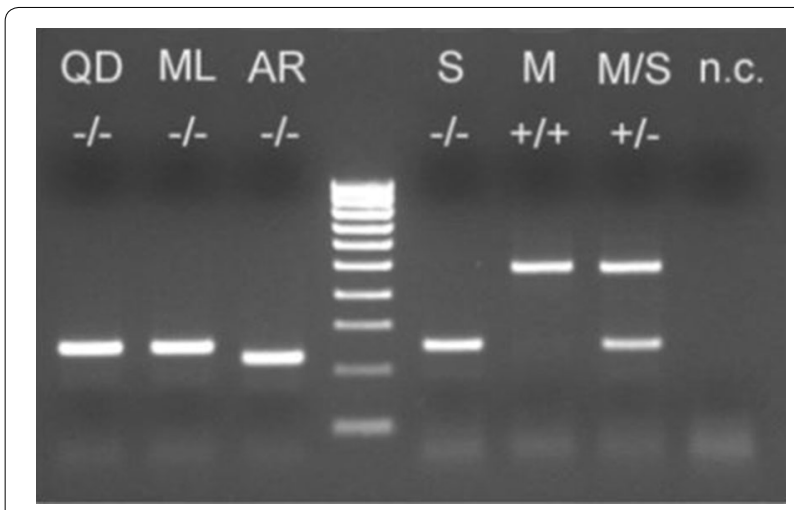

Fig. 2 PCR diagnosis based on S200 X6.1 in Anopheles gambiae s.l. PCR results from locus $\$ 200 \times 6.1$ indicating the presence (+) or absence ( - ) of the insertion in females of Anopheles gambiae species complex. $\mathrm{QD}=A$. Quadriannulatus $\mathrm{A} ; \mathrm{ML}=A$. Melas; $\mathrm{AR}=$ A. arabiensis; $\mathrm{S}=$ A. gambiae $\mathrm{S}$-form; $\mathrm{M}=$ A. gambiae $\mathrm{M}$-form; $\mathrm{M} / \mathrm{S}=\mathrm{M} / \mathrm{S}$ hybrids from laboratory crosses; n.c. $=$ negative control. Ladder $=100 \mathrm{bp}$ (BIOLINE Hyper Ladder IV) [36] the different sibling species of the An. gambiae complex, namely An. gambiae s.s., Anopheles arabiensis, An. melas, Anopheles merus, An. quadriannulatus, and Anopheles bwambae. For that, the following primers were used:

\section{UN: GTGTGCCGCTTCCTCGATGT \\ AG: CTGGTTTGGTCGGCACGTTT \\ AA: AAGTGTCCTTCTCCATCCTA \\ ME: TGACCAACCCACTCCCTTGA \\ QD: CAGACCAAGATGGTTAGTAT}

The UN primer anneals to the same position of the rDNA of all five species, and AG anneals specifically to An. gambiae. ME anneals to both An. merus and An. melas. AA anneals to An. arabiensis and QD anneals to An. quadriannulatus. The PCR was carried out using a program of 30 cycles of denaturation at $94{ }^{\circ} \mathrm{C}$ for $30 \mathrm{~s}$, annealing at $50{ }^{\circ} \mathrm{C}$ for $30 \mathrm{~s}$, and extension at $72{ }^{\circ} \mathrm{C}$ for 30 s. Amplified DNA copies are stored at a final temperature of $4{ }^{\circ} \mathrm{C}$ prior to migration on a $2.5 \%$ agarose gel with ethidium bromide used as intercalating agent and migration front.

\section{Detection of the L1014F mutation of the kdr gene}

The presence of resistance alleles (L1014F) of the $k d r$ gene in samples collected at each study site was tested using PCR, whose protocol and amplification program are described by Martinez-Torres et al. [21]. In fact, the PCR-PASA consists in using the specific primers named Agd1, Agd2, Agd3, Agd4 and Taq polymerase to search by special amplification for resistant or sensitive alleles on a fragment coding for $V g s c$ in each mosquito tested. The primer pair Agd1/Agd2 matches the $k d r$ gene by amplifying a $293 \mathrm{bp}$ product as a control. The primer pair Agd3/Agd1 is only matched to the resistance allele of the $k d r$ gene to amplify a $195 \mathrm{bp}$ fragment. Finally, the pair of Agd4/Agd2 primers associates only to the sensitive allele of the same gene by amplifying a $137 \mathrm{bp}$ fragment. The nucleotide sequences of these primers are [21]:

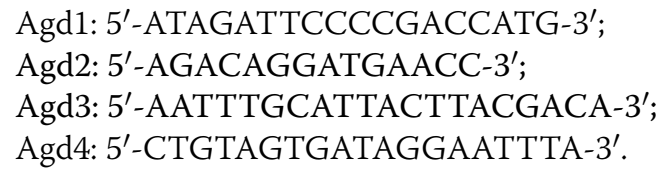

\section{Analysis of population genetic structure}

Several analytical approaches were used to establish the genetic structure of populations. The genetic constitution of each population is determined by calculating the allelic and genotypic frequencies from the $k d r$ gene. For this purpose, Genepop version 4.2 was used to calculate these frequencies. Via R version 3.3.3, The p-value associated 
with each gene frequency were calculated using the binomial law. The Hardy-Weinberg Equilibrium Test (EHW) was determined using Genetics software version 1.3.8.1 that allowed to check whether panmixia exists in the different populations of mosquitoes of the agroecological zones under study. Other indices allowing to identify the probable causes of a possible deviation from panmixia were calculated using the formulae of Weir and Cockerham [38] and Robertson and Hill [39], implemented in the Genepop version 4.2 software. These are observed heterozygoty $(\mathrm{Ho})$, expected heterozygoty $(\mathrm{He})$, expected numbers, fixation index $\left(F_{I S}\right)$ and genetic differentiation within populations $\left(F_{S T}\right)$ and between populations $\left(F_{S C}\right)$. Fixation index $\left(F_{I S}\right)$ is used to quantify the deviation to the panmixia. If $F_{I S}<0$, the population has an excess of heterozygous, otherwise $\left(F_{I S}>0\right)$, it has a heterozygous deficit and for $F_{I S}=0$, the observed heterozygosis is statistically consistent with that expected and the population is likely panmictic. The criteria used to assess genetic differentiation in populations are those defined by Hartl [40]. Depending on the values obtained, genetic differentiation is low if the $\mathrm{F}_{\mathrm{ST}}$ is less than or equal to 0.05 ; moderated when its value is between $[0.05 ; 0.15]$ and large when it is between $[0.15 ; 0.25]$. This differentiation is very large if its value is greater than 0.25 . The multiple comparison Chi square test for proportions was performed with $\mathrm{R}$ version 3.3.3.

\section{Results}

\section{Insecticide use survey}

Sixty farmers and household managers were asked about the pesticides they use. Sociological surveys have revealed that several classes of pesticides have been used in Zagnanado, Kétou and Cotonou. Those products have various commercial names, including Glyphosate 480, Herbfini, Herbex tra, Glycel, Finish, Force Up, Atrazine, Paraphosis, Fariapermefos EC, Lambda super, Pentagon, Para plus. Figure 3a displays pictures of some of the products used.

Pesticides identified during the surveys are of the classes of pyrethroids (Lambda super, Pentagon, Para plus, Para force), organophosphorus compounds (Killer $480 \mathrm{sl}$, Gramoquat super, Calriz, Adwuma Wura), organochlorines (endosulfan) and carbamates (Furadan). The proportions of each family of pesticides surveyed in the localities under study are shown in Fig. 3b.

As it can be seen in Fig. 3b, no insecticide class was reportedly used in Sô-Ava. However, this city has on several occasions, benefited from LLINs distribution campaigns. However, the effects of the various classes of pesticides, mainly pyrethroids, cannot be definitively excluded given their extensive use in public health for indoor residual spraying, and for the impregnation of distributed bed nets. With the exception of Sô-Ava, these classes of pesticides are not extensively used, organophosphates and pyrethroids are widely used in the other localities under study. Organochlorines are reported to be widely used in Cotonou and Zagnanado, while carbamates are only reported to be used in Zagnanado.

\section{Molecular characterization of the collected mosquitoes samples}

The various species of the An. gambiae complex were sampled and the results are presented in Table 2. The results presented in Table 2 showed that the collected mosquitoes were An. coluzzii, An. gambiae or rarely their hybrids. Regardless of the locality, An. coluzzii was the majority species and An. gambiae was poorly represented. The An. gambiae/An.coluzzii hybrids were found only in Cotonou in statistically insignificant proportion. The relatively small number of An. gambiae obtained across the localities did not allow a robust statistical comparison of the proportions by the localities. For this reason, the study of the genetic structure was carried out only with An. coluzzii.

\section{Genotyping of the Anopheles coluzzii species and genetic structure of the populations}

Using the site $L 1014$ of the $k d r$ gene, the genotypes of An. coluzzii in each locality were determined and the different results are presented in Table 3. Resistant homozygous individuals ( $L 1014 F / L 1014 F)$ were strongly represented across the localities with values ranging from 55.294 to $92.572 \%$. The highest rate was obtained in Cotonou (92.572\%) while the lowest was reported in SôAva (52.941\%). In both heterozygotes (L1014F/L1014L) and sensitive homozygotes $(L 1014 L / L 1014 L)$, the tendency is reversed with the highest proportions reported in Sô-Ava and the lowest in Cotonou. In each locality, the resistant homozygotes are highly represented, followed by the heterozygotes while the wild type homozygotes are poorly represented. From the Table 3 there is a significant difference accross municipalities (Cotonou, Sô-Ava, Zagnanado and Kétou) in resistant homozygous individuals $(L 1014 F / L 1014 F)$ in Cotonou, Sô-Ava, Zagnanado and Ketou $\left(x^{2}=58.442, \mathrm{df}=3, \mathrm{p}\right.$ value $\left.=1.26510^{-12}\right)$. A detailed pairwise comparison showed a significant difference in Cotonou-Sô-Ava, Cotonou-Kétou, Sô-Ava- Ketou, Sô-Ava- Ketou, Sô-Ava- Zagnanado ( $\mathrm{p}$ value $<0.05$ ), but there is no significant difference between Cotonou-Zagnanado ( $\mathrm{p}$ value $=0.1959$ ) and Zagnanado-Kétou ( $\mathrm{p}$ value $=0.7867$ ). Similar results were observed with the heterozygous individuals (L1014L/ $L 1014 F$ ) across all localities. However, no significant difference was observed across municipalities in susceptible homozygous individuals $(L 1014 L / L 1014 L)$. 
a
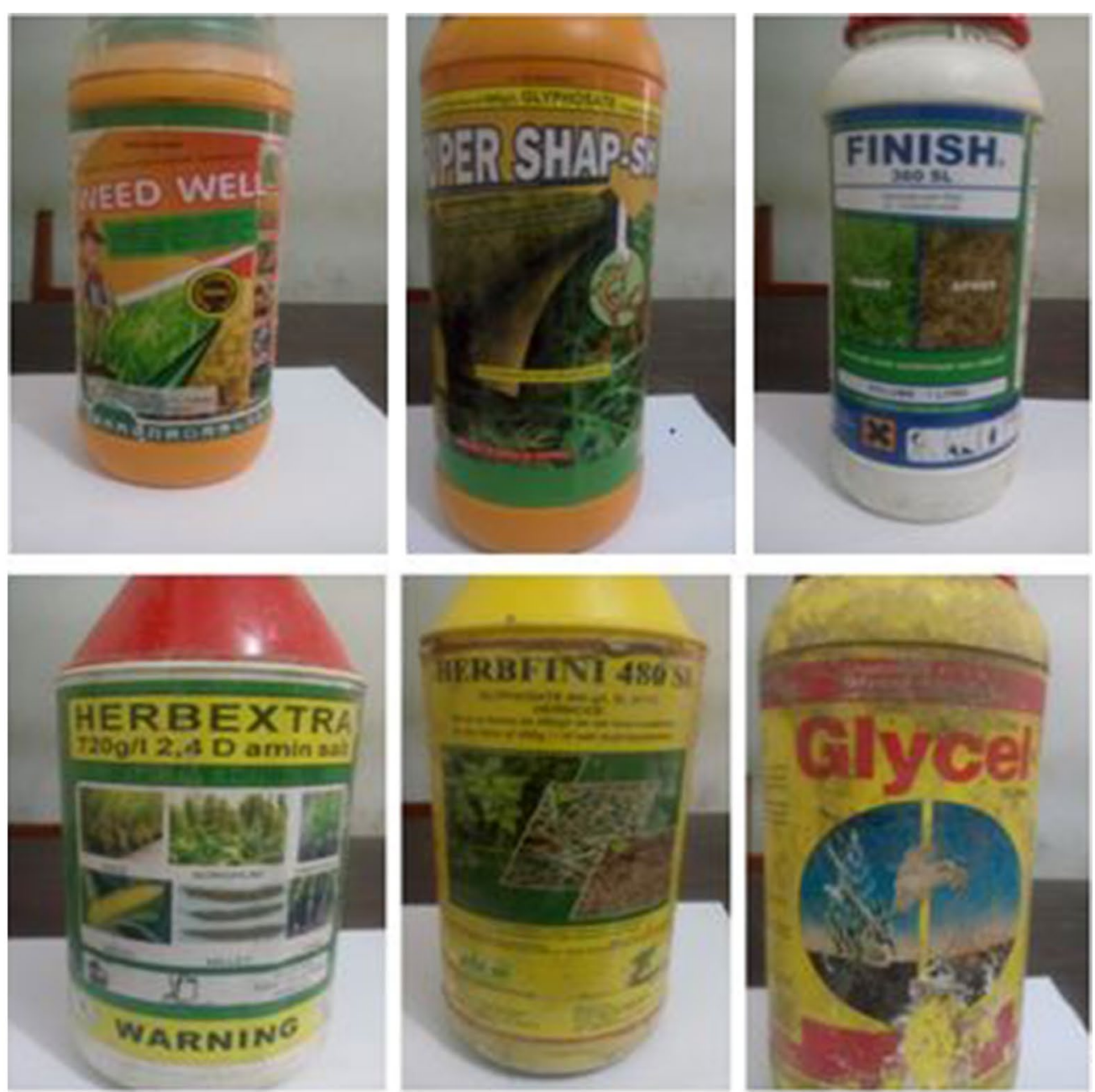

b

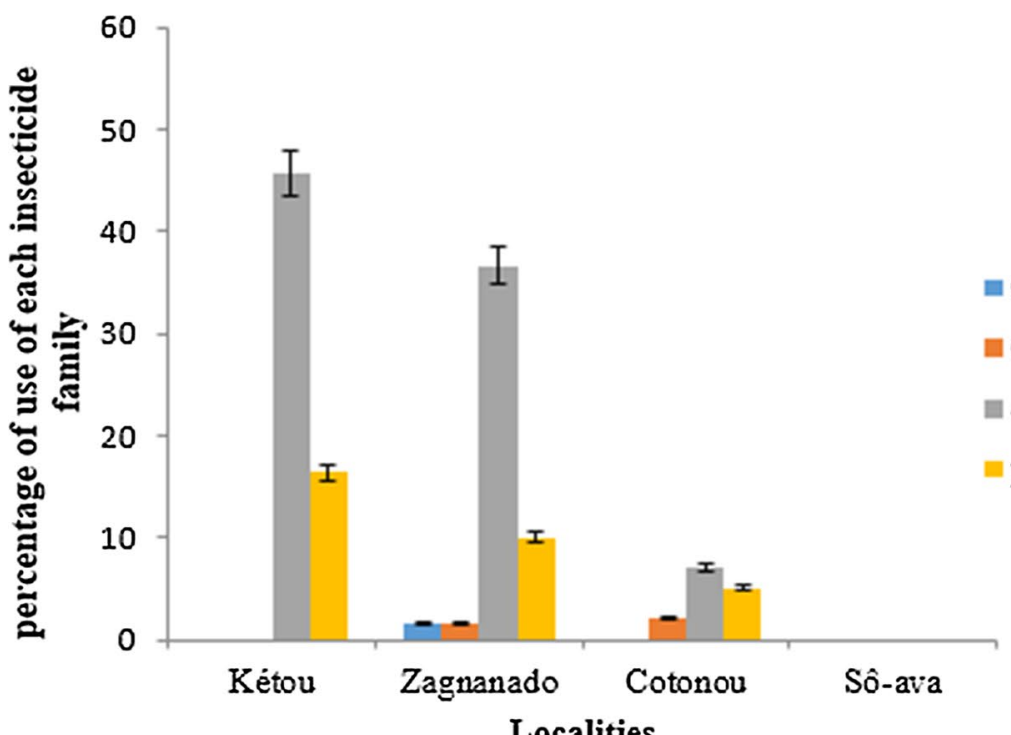

Localities

Fig. 3 a Pictures of pesticide boxes identified during the surveys. b Percentage of various pesticide classed surveyed in each locality 
Table 2 Molecular identification of An. gambiae complex species

\begin{tabular}{|c|c|c|c|c|c|c|c|c|}
\hline Localities & Collection sites (villages) & Sampling period & Latitude & Longitude & Number tested & $\begin{array}{l}\text { An. } \\
\text { coluzzii }\end{array}$ & $\begin{array}{l}\text { An. } \\
\text { gambiae }\end{array}$ & $\begin{array}{l}\text { Hybrids } \\
\text { forms }\end{array}$ \\
\hline \multirow[t]{19}{*}{ Cotonou } & Fidjrossè & Rainy season & $6^{\circ} 21^{\prime} 36.90^{\prime \prime} N$ & $2^{\circ} 22^{\prime} 15.08^{\prime \prime} \mathrm{E}$ & 9 & 9 & 0 & 0 \\
\hline & Agla & Rainy season & $6^{\circ} 23^{\prime} 01.36^{\prime \prime} N$ & $2^{\circ} 21^{\prime} 50.72^{\prime \prime} \mathrm{E}$ & 8 & 8 & 0 & 0 \\
\hline & Vossa & Rainy season & $6^{\circ} 23^{\prime} 21.57^{\prime \prime} \mathrm{N}$ & $2^{\circ} 24^{\prime} 21.57^{\prime \prime} \mathrm{E}$ & 20 & 17 & 1 & 2 \\
\hline & Menontin & Rainy season & $6^{\circ} 23^{\prime} 34.85^{\prime \prime} N$ & $2^{\circ} 21^{\prime} 55.16^{\prime \prime} \mathrm{E}$ & 10 & 10 & 0 & 0 \\
\hline & Kouhounou & Rainy season & $6^{\circ} 23^{\prime} 20.26^{\prime \prime} N$ & $2^{\circ} 22^{\prime} 44.02^{\prime \prime} \mathrm{E}$ & 5 & 5 & 0 & 0 \\
\hline & Vedoko & Rainy season & $6^{\circ} 22^{\prime} 43.97^{\prime \prime} N$ & $2^{\circ} 23^{\prime} 17.26^{\prime \prime} \mathrm{E}$ & 5 & 5 & 0 & 0 \\
\hline & Fifadji & Rainy season & $6^{\circ} 23^{\prime} 52.42^{\prime \prime} \mathrm{N}$ & $2^{\circ} 23^{\prime} 59.65^{\prime \prime} \mathrm{E}$ & 9 & 9 & 0 & 0 \\
\hline & Zogbo & Rainy season & $6^{\circ} 23^{\prime} 34.40^{\prime \prime} \mathrm{N}$ & $2^{\circ} 23^{\prime} 32.89^{\prime \prime} \mathrm{E}$ & 5 & 5 & 0 & 0 \\
\hline & Ste Rita & Rainy season & $6^{\circ} 23^{\prime} 00.58^{\prime \prime} N$ & $2^{\circ} 23^{\prime} 50.65^{\prime \prime} \mathrm{E}$ & 5 & 5 & 0 & 0 \\
\hline & Ladji & Rainy season & $6^{\circ} 23^{\prime} 24.31^{\prime \prime} \mathrm{N}$ & $2^{\circ} 25^{\prime} 43.89^{\prime \prime} \mathrm{E}$ & 32 & 32 & 0 & 0 \\
\hline & Houéyiho & Rainy season & $6^{\circ} 22^{\prime} 17.26^{\prime \prime} \mathrm{N}$ & $2^{\circ} 23^{\prime} 50.47^{\prime \prime} \mathrm{E}$ & 18 & 18 & 0 & 0 \\
\hline & Dandji & Rainy season & $6^{\circ} 21^{\prime} 42.63^{\prime \prime} \mathrm{N}$ & $2^{\circ} 29^{\prime} 42.62^{\prime \prime} \mathrm{E}$ & 10 & 9 & 1 & 0 \\
\hline & Agbato & Rainy season & $6^{\circ} 23^{\prime} 40.72^{\prime \prime} N$ & $2^{\circ} 26^{\prime} 37.42^{\prime \prime} \mathrm{E}$ & 7 & 7 & 0 & 0 \\
\hline & Agbodjedo & Rainy season & $6^{\circ} 23^{\prime} 33.46^{\prime \prime} N$ & $2^{\circ} 26^{\prime} 57.46^{\prime \prime} \mathrm{E}$ & 9 & 8 & 0 & 1 \\
\hline & Yénawa & Rainy season & $6^{\circ} 23^{\prime} 23.94^{\prime \prime} N$ & $2^{\circ} 27^{\prime} 24.26^{\prime \prime} \mathrm{E}$ & 12 & 12 & 0 & 0 \\
\hline & Sènandé & Rainy season & $6^{\circ} 22^{\prime} 42.86^{\prime \prime} \mathrm{N}$ & $2^{\circ} 27^{\prime} 35.34^{\prime \prime} \mathrm{E}$ & 6 & 5 & 1 & 0 \\
\hline & Ayélawadjè & Rainy season & $6^{\circ} 23^{\prime} 33.48^{\prime \prime} N$ & $2^{\circ} 26^{\prime} 48.54^{\prime \prime} \mathrm{E}$ & 7 & 5 & 2 & 0 \\
\hline & Gankpodo & Rainy season & $6^{\circ} 23^{\prime} 21.29^{\prime \prime} \mathrm{N}$ & $2^{\circ} 27^{\prime} 35.27^{\prime \prime} \mathrm{E}$ & 6 & 6 & 0 & 0 \\
\hline & Total & & & & 183 & 175 & 5 & 3 \\
\hline \multirow[t]{6}{*}{ Sô-Ava } & Houndomè1 & Dry season & $6^{\circ} 28^{\prime} 18^{\prime \prime} 24 \mathrm{~N}$ & $2^{\circ} 24^{\prime} 06.83^{\prime \prime} \mathrm{E}$ & 9 & 9 & 0 & 0 \\
\hline & Houndomè2 & Dry season & $6^{\circ} 28^{\prime} 16.52^{\prime \prime} \mathrm{N}$ & $2^{\circ} 24^{\prime} 02.74^{\prime \prime} \mathrm{E}$ & 10 & 10 & 0 & 0 \\
\hline & Dogodo & Rainy season & $6^{\circ} 28^{\prime} 05.22^{\prime \prime} N$ & $2^{\circ} 24^{\prime} 57.09^{\prime \prime} \mathrm{E}$ & 15 & 15 & 0 & 0 \\
\hline & Sô-Tchanhoué & Rainy season & $6^{\circ} 28^{\prime} 33.45^{\prime \prime} \mathrm{N}$ & $2^{\circ} 24^{\prime} 50.90^{\prime \prime} \mathrm{E}$ & 21 & 21 & 0 & 0 \\
\hline & Ganvié & Rainy season & $6^{\circ} 28^{\prime} 01.28^{\prime \prime} \mathrm{N}$ & $2^{\circ} 24^{\prime} 58.99^{\prime \prime} \mathrm{E}$ & 30 & 30 & 0 & 0 \\
\hline & Total & & & & 85 & 85 & 0 & 0 \\
\hline \multirow[t]{5}{*}{ Kétou } & Kétou centre & Rainy season & $7^{\circ} 21^{\prime} 37.44^{\prime \prime} N$ & $2^{\circ} 36^{\prime} 14.24^{\prime \prime} \mathrm{E}$ & 8 & 8 & 0 & 0 \\
\hline & Odometa (Oloka) & Dry season & $7^{\circ} 21^{\prime} 13.39^{\prime \prime} \mathrm{N}$ & $2^{\circ} 36^{\prime} 48.34^{\prime \prime} \mathrm{E}$ & 32 & 28 & 4 & 0 \\
\hline & Kpankou & Rainy season & $7^{\circ} 21^{\prime} 58.34^{\prime \prime} N$ & $2^{\circ} 36^{\prime} 17.87^{\prime \prime} \mathrm{E}$ & 22 & 19 & 3 & 0 \\
\hline & Mowodani & Rainy season & $7^{\circ} 21^{\prime} 42.88^{\prime \prime} \mathrm{N}$ & $2^{\circ} 35^{\prime} 59.21^{\prime \prime} \mathrm{E}$ & 28 & 25 & 3 & 0 \\
\hline & Total & & & & 90 & 80 & 10 & 0 \\
\hline \multirow[t]{5}{*}{ Zagnanado } & Zagnanado-centre & Rainy season & $7^{\circ} 12^{\prime} 44.53^{\prime \prime} N$ & $2^{\circ} 20^{\prime} 31.99^{\prime \prime} \mathrm{E}$ & 24 & 20 & 4 & 0 \\
\hline & Kpédékpo & Rainy season & $7^{\circ} 12^{\prime} 40.56^{\prime \prime} \mathrm{N}$ & $2^{\circ} 20^{\prime} 26.71^{\prime \prime} \mathrm{E}$ & 18 & 15 & 3 & 0 \\
\hline & Bamé & Rainy season & $7^{\circ} 12^{\prime} 47.82^{\prime \prime} N$ & $2^{\circ} 20^{\prime} 19.32^{\prime \prime} \mathrm{E}$ & 18 & 17 & 1 & 0 \\
\hline & Houègbo-centre & Rainy season & $7^{\circ} 12^{\prime} 39.86^{\prime \prime} N$ & $2^{\circ} 20^{\prime} 27.40^{\prime \prime} \mathrm{E}$ & 14 & 12 & 2 & 0 \\
\hline & Total & & & & 74 & 64 & 10 & 0 \\
\hline Total & & & & & 432 & 404 & 25 & 3 \\
\hline
\end{tabular}

On the one hand, the equilibrium of Hardy-Weinberg (EHW) has not been observed in the An. coluzzii population of Cotonou, Kétou and Zagnanado as it can easily be seen in Table 3 (p-value $<0.001$ ). On the other hand, this panmixia seems to be observed in the An. coluzzii population of Sô-Ava (p-value =0.7882). In order to confirm the EHW in Sô-Ava, the contingency test of $\chi^{2}$ at $\mathrm{ddl}=1$ was performed to allow us sufficient robustness and confidence on the conclusions to be drawn. For this purpose, the theoretically expected number of each genotype have been calculated. These numbers are 44.3964, 34.2071, 6.3964 for genotypes $L 1014 F / L 1014 F, L 1014 F / L 1014 L$, L1014L/L1014L, respectively.

$$
X^{2}=\left[(45-44.3964)^{2} /(44,3964)+(33-34.2071)^{2} /\right.
$$
$\left.(34.2071)+(7-6.3964)^{2} /(6.3964)\right]=0.1077$. The probability for $\mathrm{ddl}=1$ associated with this value of $\chi^{2}$ is 0.7427 which is both contained in the domain of validity and very close to that (0.7882) displayed by the p-value. 
Table 3 Genotyping of An. coluzzii individuals, and assessment of the allelic and genotypic frequencies

\begin{tabular}{|c|c|c|c|c|c|c|}
\hline \multirow[t]{2}{*}{ Localities } & \multicolumn{3}{|c|}{ Number of genotype and frequencies in $\%$} & \multirow{2}{*}{$\begin{array}{l}\mathrm{F} \% \\
\text { (L1014F) }\end{array}$} & \multirow{2}{*}{$\begin{array}{l}\mathrm{p} \text {-value } \\
F(L 1014 F)\end{array}$} & \multirow{2}{*}{$\begin{array}{l}p \text {-value } \\
\text { (EHW) }\end{array}$} \\
\hline & L1014F/L1014F & L1014L/L1014F & L1014L/L1014L & & & \\
\hline Cotonou & $162(92.572) a$ & $10(5.714) a$ & $3(1.714) a$ & 95.428 & $<0.001$ & 0.0026 \\
\hline Sô-Ava & $45(52.941) b$ & $33(38.824) b$ & $7(8.235) a$ & 72.353 & $<0.001$ & 0.7882 \\
\hline Zagnanado & $54(84.376) \mathrm{ac}$ & $5(7.812) \mathrm{ac}$ & $5(7.812) \mathrm{a}$ & 88.281 & $<0.001$ & $<0.001$ \\
\hline Kétou & $65(81.250) c$ & $10(12.500) \mathrm{C}$ & $5(5.250) a$ & 87.500 & $<0.001$ & $<0.001$ \\
\hline
\end{tabular}

L1014F/L1014F: resistant homozygous; L1014L/L1014F: heterozygous; L1014L/L1014L: sensitive homozygous; F(L1014F): Frequency of resistance allele; p-value F(L1014F): threshold of significance of the frequency of the allele L1014F; p-value (EHW): p-value at the Hardy-Weinberg Equilibrium

Frequencies with the same letter in columns do not differ significantly from one locality to another

Table 4 Difference in Panmixia, genetic differentiation within An. coluzzii populations

\begin{tabular}{llllc}
\hline Localities & Ho & He & $\boldsymbol{F}_{\text {IS }}(\mathbf{W} \& \mathbf{C})$ & $\boldsymbol{F}_{\boldsymbol{S T}}(\mathrm{W} \& \mathrm{C})$ \\
\hline Cotonou & 0.057 & 0.087 & 0.348 & 0.056 \\
Sô-Ava & 0.388 & 0.402 & $-0.035 \approx 0$ & -0.018 \\
Kétou & 0.125 & 0.220 & 0.434 & -0.0049 \\
Zagnanado & 0.078 & 0.208 & 0.627 & -0.0464
\end{tabular}

Ho: observed heterozygoty; He: expected heterozygoty; $F_{I S}$ : fixation index; $F_{S T}$ : differentiation index; W\&C: Weir \& Cockerham

\section{Deviation from panmixia and genetic differentiation}

Table 4 presents the observed heterozygoties $(\mathrm{Ho})$ and expected heterozygoties $(H e)$, fixation index $\left(F_{I S}\right)$, genetic differentiations $\left(F_{S T}\right)$, in $A n$. coluzzii populations across the localities.

The observed heterozygosity was lower than that expected in the populations. EHW has not been observed in most populations. The heterozygosity deficit was widely shared among the $A n$. coluzzii populations except for Sô-Ava. No genetic differentiation was observed in the $A n$. coluzzii populations of Zagnanado and Ketou $\left(F_{S T}<0\right)$. Nevertheless, this differentiation was moderate in Cotonou.

\section{Discussion}

The surveys conducted on the utilization of insecticide identified four classes of pesticides in the localities with variable use against mosquito vectors and other pests. Except for Sô-Ava, pyrethroids and organophosphates are the mostly used classes of pesticides. This is not surprising since previous studies have shown in Benin that these two classes of insecticides are predominantly used in agriculture against crop pests, and also in public health in the fight against malaria-carrying insects [41]. The study results indicate a very low percentage of organochlorine use in Zagnanado. This class of insecticide is not even registered in the other localities. The probable reasons justifying this observation is the prohibition of organochlorine use in Benin due to its wide spread contamination of the ecosystem including surface waters and fish populations. In addition, organochlorines easily accumulate in sediments [42]. However, it may well be assumed that a sufficiently large increase in the size of the respondents would have revealed a higher use of this class of pesticide in the study localities. In Sô-Ava for instance, no insecticide use was reported. The absence of agricultural practices is probably the basis for such an observation. Similarly, the relatively low number of respondents is another probable justification of the reported absence of pesticide use in Sô-Ava. With human dwellings becoming increasingly modern, and the use of fine build materials, supplemental data on the use of LLINs are necessary to better assess pesticide selection pressure of resistant mosquitoes in this locality.

Anopheles coluzzii is strongly represented across all study localities. Corbel et al. [42] reported that $A n$. coluzzii is the predominant species (>98\%) in southern Benin. In Cotonou and Sô-Ava, the constant presence of water favours the availability of breeding sites and the rapid reproduction of mosquitoes. In this study, molecular identification of the collected mosquito samples clearly shows that the different species live in sympathy with a predominance of $A n$. coluzzii, thus confirming the same observation reported by other studies [43-45]. Mosquito larvae were harvested from standing water puddles, abandoned canoes and even heavily polluted pits throughout the study. Kudom showed in Ghana that An. coluzzii develops in polluted waters and in permanent and semi-permanent breeding sites [46]. This observation leads us to believe in ecological adaptation of the species likely related to current climate change. In the recent past, Gimoneau et al. [47] have reported that permanent mosquito breeding sites are the main habitats for $A n$. coluzzii, while temporary breeding sites are colonized by $A n$. gambiae. In Kétou and Zagnanado, the predominance of $A n$. coluzzii still reflects the high distribution of this species in southern Benin as reported in previous studies 
[42]. The dominance of this species in Zagnanado can also be explained by the presence of permanent breeding sites on the rice production site. After molecular characterization of previously morphologically identified individuals, the An. gambiae species was poorly represented while its twin sister species An. coluzzii was dominant in all localities. The few numbers of $A n$. gambiae collected could only be related to the collection method used (larvae collection) due to difficult access to the majority of An. gambiae breeding sites. Adult collections generally show a more diverse species composition than those observed in larvae collections.

The relatively high frequency of $L 1014 \mathrm{~F}$ allele of the $k d r$ gene observed in Sô-Ava despite the reported absence of pesticide use remains to be carefully investigated. The proximity of Cotonou to Sô-Ava may explain the relatively high pesticide selection of resistant mosquitoes in Sô-Ava. In fact, resistant mosquitoes could migrate from Cotonou to colonize the surroundings of Sô-Ava. For example, Nkya et al. [48] showed that a high frequency of resistance alleles of the $k d r$ gene is associated with an overproduction of cytochrome $\mathrm{P} 450$ gene products (CYP9J4 and CYP6P1) and alpha esterases AGAP006227 in a region where insecticide pressure is low but very close to an agricultural area in Kilimanjaro, Tanzania where the use of these synthetic substances is intense. It appears that this pattern of joint metabolic actions is conducive to the survival of the mosquito, and is one that is shared by populations of mosquitoes of the same lineage. Further Biochemical investigations on the detoxification of toxic chemicals are essential in populations of An. coluzzii. In the case of Sô-Ava, the use of long-lasting insecticidal nets (LLINs) with other unknown factors potentially favour the selection of resistant individuals in this locality. Pesticides use in vector control is considered to be the main cause of resistance emergence in mosquito populations $[45,49]$.

In Cotonou, a high frequency of $L 1014 F$ allele was observed. Yadouleton et al. [12] showed that the use of pesticides in the market areas of Houéyiho located in Cotonou could lead to a strong selection of resistant individuals. The water availability associated with the hydromorphic nature of the soil of this locality (Fishery Zone) could lead to a rapid spread of selected resistant individuals in the market area and other unidentified locations. This would largely justify the rapid expansion of resistant individuals throughout the city. Several studies have shown that the use of insecticides against crop pests and the presence of pollutants in urban and industrial areas can play a significant role in the selection of resistance in mosquitoes [50]. Other studies have also showed that the use of pollutants in urban areas can influence the detoxification mechanisms of mosquitoes leading to better tolerance of mosquitoes to insecticides [51-53].

A high frequency of $L 1014 \mathrm{~F}$ allele was also observed in Ketou and Zagnanado. The main crops in these areas were found to be cotton and rice, respectively [31, 32]. Producers use several classes of insecticides to protect their crops from pests. The development of agriculture through the massive use of pesticides is concurrently associated with a high level of resistance of malaria vectors to insecticides in West Africa [54-56]. In fact, most pesticides used by farmers are also used in public health for mosquito bed net impregnation and indoor spraying [12]. This practice potentially increases the selection pressure of resistant individuals in mosquito populations. The emergence of pyrethroid resistance in An. gambiae has become a major concern for the success of malaria control in the last decade $[57,58]$. This insecticide class remains the only one used for mosquito net impregnation, the main control strategy against malaria vectors $[59,60]$. At the molecular level, action sites for several classes of insecticides are widely shared by many taxa whether or not they are phylogenetic. Future biochemical and molecular studies could focus more on these aspects which could contribute to the improvement of knowledge on resistance mechanisms developed by local taxa.

In the municipalities of Cotonou, Zagnanado and Kétou, a high selection of the $L 1014 F$ allele was observed, which was observed by the high frequency of the L1014F/ L1014F genotypes. Several studies have shown in Benin, in the sub-region and throughout Africa that its resistance has been associated with high pesticide use. For example, in Burkina Faso, the work of Dabire et al. [61] showed that the link between agriculture and pyrethroid resistance was confirmed by a significant correlation between deltamethrin resistance levels and agricultural intensification in all populations. The authors discuss the fact that agriculture and urban areas are likely to promote the emergence of insecticide resistance. In agricultural areas, the main factor is the massive use of pesticides and in urban areas, uncontrolled indoor spraying of insecticides can strongly promote $k d r$ mutations. Similarly, resistance to DDT and pyrethroids from An. gambiae s.s. populations in urban and agro-industrial environments has been observed in southern Cameroon [62].

At this stage, the genetic structure suggests that directional selection seems to be predominant in the populations of An. coluzzii exposed to insecticides and, in some cases, an almost total loss of molecular polymorphism was observed, with a frequency of the resistant allele $L 1014 F$ exceeding $95 \%$. In light of the results of this study and in the current environment, the selective value of resistant homozygotes $L 1014 F / L 1014 F$ is likely higher 
than that of heterozygotes $L 1014 F / L 1014 L$ which is in turn, higher than that of sensitive homozygotes $L 1014 L /$ L1014L. In the current context, studies on the ecological adaptation of disease vectors need to be deepened in order to provide further clarification on mosquito ethology.

The EHW was observed in Sô-Ava. Since this locality is a lake city with a permanent presence of water and a strong wind action, it is not excluded that these factors mitigate or inhibit the effect of insecticides in the Anopheles population. This situation can explain the relatively high p-values (Table 3 ), suggesting a high risk of second-order error due to the apparently small sample size. Alternatively, the molecular marker used may be illsuited and this study may have to go to a higher level of resolution such as nucleotide sequencing where the different haplotypes could be easily detected.

The fixation index calculated in the localities of Cotonou, Kétou and Zagnanado shows that all populations display a gap in panmixia. Heterozygous deficiency is generally observed in populations of these communities. It has been shown in population genetics that the causes of such an equilibrium gap of Hardy-Weinberg can be the Wahlund effect, inbreeding, genetic drift, selection against heterozygotes or their combination. Based on the results of the sociological surveys, it is tempting to believe in a situation of strong selection ofthe $L 1014 \mathrm{~F}$ allele even if other factors may be involved. This observation would result in the effect of pesticides on mosquitoes which eliminate susceptible individuals leaving first-generation resistant individuals inbreed because of their limited population size. The resulting offspring will transmit almost exclusively the resistance allele to their descendants and, therefore, ensure the expansion of the resistance genetic mutation within the populations. Several studies have documented on the African continent, the role of chemical use in the development and spread of resistance. Such studies carried out in Benin [63], Cameroon [62], Sudan [64] and other African countries, have associated the increasing resistance of mosquitoes to insecticides with the increased use of pesticides.

No genetic differentiation was observed in the populations of mosquitoes of Zagnanado and Kétou. With these two localities being geographically close, this finding may be related to an apparent homogeneity of biotic and abiotic factors that could create genetic differentiation between individuals, and to some extent to the resolution power of the type of marker used. Moderate genetic differentiation in the population of mosquitoes of Cotonou may be rooted in the extrinsic factors capable of exerting, among others, insecticide pressures on the individuals of this population.
Genotypic differentiation within the different populations of the localities studied shows that genotypes are distributed similarly to Sô-Ava despite the fact the use of any class of pesticides was registered in that community. In one way or another, this observation suggests that there are several other unidentified factors which are involved in the distribution of An. coluzzii. The use of LLINs could also contribute to the selection of resistant individuals [65].

\section{Conclusions}

The survey on the use of insecticides showed that insecticide selection pressures differ across the investigated localities. Although vector control programmes depend exceptionally on the use of residual insecticides, they should be preceded by a study of the genetic structure of vector populations because it depends essentially on the ecology of the environment and the genetic pool of vector populations. It would be desirable to rotate or apply formulations of combined products with different modes of action. Doing so would enable a better management of resistant homozygous individuals, and mitigate the resistance effect of commonly used insecticides. Further investigations using other methodological approaches such as microsatellites and nucleotide sequencing of appropriate genes providing a higher resolution, are necessary. Such deeper investigations may provide a better evaluation of the genetic differentiation within and between populations of disease vectors and assess the impact of the environment on their genetic structure and diversity.

\section{Abbreviations}

WHO: World Health Organization; IRS: indoor residual spraying; An:: Anopheles; LLIN: long-lasting insecticidal nets; IRS: indoor residual spraying; DNA: desoxyribonucleic acid; $C T A B$ : cetyl trimethyl ammonium bromide; PCR: polymerase chain reaction; Kdr: knock down resistance; vgsc: voltage gate sodium chanel; HWE: Hardy-Weinberg Equilibrium; IGS: intergenic spacer; W\&C: Weir \& Cockerham; Ho: observed heterozygosity; He: expected heterozygosity; Fis: fixation index; Fst: genetic differentiations within populations; Fsc: genetic differentiations between populations.

\section{Acknowledgements}

We thank the Ministry of Higher Education and Scientific Research (MESRS) and the Cotonou Entomological Research Centre (CREC) for their technical assistance during our field and laboratory work. We are also grateful to Wilfrid T. Sèwadé, Aboubakar Sidick, Albert S. Salako and Idelphonse Ahogni for their participation to the study's activities.

\section{Authors' contributions}

AJYHF, MS, RAO and MCA designed the study. AJYHF, CZK, CK, AS, YB and HS performed the experiments. AJYHF, RA and MS analysed the data. AJYHF wrote the manuscript. AJYHF, CK, FRA, MCA, RAO and MS criticized and revised the manuscript. All authors read and approved the final manuscript.

Funding

Not applicable 


\section{Availability of data and materials}

The data supporting the conclusions of this article are included within the article. The raw data used and/or analyzed in this study are available from the corresponding author upon reasonable request

\section{Ethics approval and consent to participate}

Not applicable.

\section{Consent for publication}

Not applicable.

\section{Competing interests}

The authors declare that they have no competing interests.

\section{Author details}

${ }^{1}$ Centre de Recherche Entomologique de Cotonou (CREC), Cotonou, Benin.

${ }^{2}$ Laboratoire Evolution Biodiversité des arthropodes et Assainissement, Faculté des Sciences et Techniques/Université d'Abomey-Calavi (FAST/UAC), Abomey-Calavi, Benin. ${ }^{3}$ Ecole Doctorale Sciences de la Vie et de la Terre (EDSVT/FAST/UAC), Abomey-Calavi, Benin. ${ }^{4}$ Université Nationale d'Agriculture (UNA), Porto-Novo, Benin.

Received: 1 May 2019 Accepted: 26 November 2019

Published online: 05 December 2019

\section{References}

1. Failloux AB, Falcoz MV, Mousson L, Rodhain F. Contrôle génétique de la compétence vectorielle des moustiques du genre Aedes. Unité d'écologie des systèmes vectoriels 1999.

2. WHO. World malaria report 2017. Geneva, World Health Organization; 2017. http://www.who.int/malaria/publications/world-malaria-repor $\mathrm{t}-2017 / \ldots / \mathrm{fr} / 1$.

3. WHO. World malaria report 2008. Geneva: World Health Organization; 2008.

4. Ngufor C, N'Guessan R, Boko P, Odjo A, Vigninou E, Asidi A, et al. Combining indoor residual spraying with chlorfenapyr and long-lasting insecticidal bed nets for improved control of pyrethroid-resistant Anopheles gambiae: an experimental hut trial in Benin. Malar J. 2011;10:343.

5. Akogbéto MC, Padonou GG, Gbénou D, Irish S, Yadouleton A. Bendiocarb, a potential alternative against pyrethroid resistant Anopheles gambiae in Benin, West Africa. Am J Trop Med Hyg. 2010;101:230-41.

6. Mashauri FM, Kinung'hi SM, Kaatano GM, Magesa SM, Kishamawe C, Mwanga JR, et al. Impact of indoor residual spraying of lambda-cyhalothrin on malaria prevalence and anemia in an epidemic-prone district of Muleba, north-western Tanzania. Am J Trop Med Hyg. 2013;88:841-9.

7. Lindsay SW, Martens P. Malaria in the African highlands: past, present and future. Bull World Health Organ. 1998;76:33-45.

8. Molineaux $L$. The epidemiology of human malaria as an explanation of its distribution, including some implications for its control. In: Wernsdorfer WH, McGregor I, editors. Malaria: principles and practice of malariology, vol. 2. Edinburgh: Churchill Livingstone; 1988. p. 913-98.

9. Philbert A, Lyantagaye SL, Nkwengulila G. A review of agricultural pesticides use and the selection for resistance to insecticides in malaria vectors. Adv Entomol. 2014;2:120-8.

10. Nkya TE, Poupardin R, Laporte F, Akhouayri I, Mosha F, Magesa S, et al. Impact of agriculture on the selection of insecticide resistance in the malaria vector Anopheles gambiae: a multigenerational study in controlled conditions. Parasit Vectors. 2014;7:480-91.

11. Yadouleton A, Baba-Moussa L, Klotoe JR, Coulibaly T, Tchibozo C, et al. Detection of multiple insecticide resistance mechanisms in Anopheles gambiae s.l. populations from the vegetable farming area of Houeyiho, Southern Benin, West Africa, West Africa. IJMR. 2018;5:21-7.

12. Yadouleton AW, Asidi A, Djouaka RF, Braima J, Agossou CD, Akogbéto M. Development of vegetable farming: a cause of the emergence of insecticide resistance in populations of Anopheles gambiae in urban areas of Benin. Malar J. 2009;8:103.

13. Akogbéto M, Yakoubou AW. Résistance des vecteurs du paludisme vis-àvis des pyréthrinoïdes utilisés pour l'imprégnation des moustiquaires au Benin, Afrique de l'Ouest. Bull Soc Pathol Exot. 1999;92:123-30.
14. Yadouleton AW, Padonou G, Asidi A, Moiroux N, Bio-Bangana S, Corbel $V$, et al. Insecticide resistance status in Anopheles gambiae in southern Benin. Malar J. 2010:9:83.

15. Czeher C, Labbo R, Arzika I, Duchemin JB. Evidence of increasing Leu-Phe knockdown resistance mutation in Anopheles gambiae from Niger following a nationwide long-lasting insecticide-treated nets implementation. Malar J. 2008;7:189.

16. Trape JF, Tall A, Diagne N, Ndiath O, Alioune B, Faye J, et al. Malaria morbidity and pyrethroid resistance after the introduction of insecticidetreated bed nets and artemisinin-based combination therapies: a longitudinal study. Lancet Infect Dis. 2011;11:925-32.

17. Ranson H, N'guessan R, Lines J, Moiroux N, Nkuni Z, Corbel V. Pyrethroid resistance in African anopheline mosquitoes: what are the implications for malaria control? Trends Parasitol. 2011;27:91-8.

18. Nwane P, Etang J, Chouaibou M, Toto J, Koffi A, Mimpfoundi R, et al. Multiple insecticide resistance mechanisms in Anopheles gambiae s.l. populations from Cameroon, Central Africa. Parasit Vectors. 2013;6:41.

19. Nwane P, Etang J, Chouaibou M, Toto J, Mimpfoundi R, Simard F. Kdr based insecticide resistance in Anopheles gambiae s.s. populations in Cameroon: spread of the L1014F and L1014S mutations. BMC Res Notes. 2011;4:463.

20. Ranson H, Jensen B, Vulule JM, Wang X, Hemingway J, Collins FH. Identification of a point mutation in the voltage-gated sodium channel gene of Kenyan Anopheles gambiae associated with resistance to DDT and pyrethroids. Insect Mol Biol. 2000;9:491-7.

21. Martinez-Torres D, Chandre F, Williamson MS, Darriet F, Berge JB, Devonshire AL, et al. Molecular characterization of pyrethroid knockdown resistance $(\mathrm{kdr})$ in the major malaria vector Anopheles gambiae s.s. Insect Mol Biol. 1998;7:179-84.

22. Tsagkarakou A, Navajas M, Lagnel J, Pasteur N. Population structure in the spider mite Tetranychus urticae (Acari: Tetranychidae) from Crete based on multiple allozymes. Heredity. 1997;78:84-92.

23. Chevillon C, Eritja R, Pasteur N, Raymond M. Commensalism, adaptation and gene flow: mosquitoes of the Culex pipiens complex in different habitats. Genet Res. 1995;66:147-57.

24. McCauley DE. The effect of host plant size variation on the population structure of a specialist herbivore insect Tetraopes tetraophthalmus. Evolution. 1991:45:1675-84.

25. Wade MJ, McCauley DE. Extinction and colonization: their effects on the genetic differentiation of local populations. Evolution. 1988:42:995-1005.

26. Chen H, Minakawa N, Beier J, Yan G. Population genetic structure of Anopheles gambiae mosquitoes on Lake Victoria islands, west Kenya. Malar J. 2012;3:48.

27. Gorrochotegui EN, Gomez MC, Lozano FS, Fernandez SL, De LourdesMuñoz ML, Farfan-Ale JA, et al. The breeding structure of Aedes aegypti populations in Mexico varies by region. Am J Trop Med Hyg. 2002;66:213-22.

28. Rapport national sur le développement humain: Agriculture, Sécurité alimentaire et Développement Humain au Bénin; 2015 p. 54-58.

29. Monographie de la ville de Cotonou, RGPH; 2013.

30. Monographie de la ville de Sô-Ava, RGPH; 2013.

31. Monographie de la ville de Zagnanado, RGPH; 2013.

32. Monographie de la ville de Kétou, RGPH; 2013.

33. Service MW. Mosquito ecology: field sampling methods, vector biology and control. 2nd ed. London: Elsevier Science Publishers; 1993. p. 583.

34. Yaro AS, Daro A, Adamou A, Crawford JE, Traore SF, Touré AM, et al. Reproductive output of female Anopheles gambiae (Diptera: Culicidae). Comparison of molecular forms. J Med Entomol. 2006;43:833-9.

35. Clements AN. The physiology of mosquitoes. New York: Pergamon; 1963. p. 393.

36. Santolamazza F, Calzetta M, Etang J, Barrese E, Dia I, Caccone A, et al. Distribution of knockdown resistance mutations in Anopheles gambiae molecular forms in west and west-central Africa. Malar J. 2008;7:192.

37. Scott JA, Brogdon WG, Collins FH. Identification of single specimens of the Anopheles gambiae complex by the polymerase chain reaction. Am J Trop Med Hyg. 1993;49:520-9.

38. Weir BS, Cockerham CC. Estimating F-statistics for the analysis of population structure. Evolution. 1984:38:1358-70.

39. Robertson A, Hill WG. Deviations from Hardy-Weinberg proportions: sampling variances and use in estimation of inbreeding coefficients. Genetics. 1984;107:703-18. 
40. Hartl DL. Génétique des populations. Médecine-Sciences, éditions Flammarion. 1994, p. 305.

41. Corbel V, N'Guessan R, Brengues C, Chandre F, Djogbenou L, Martin $\mathrm{T}$, et al. Multiple insecticide resistance mechanisms in Anopheles gambiae and Culex quinquefasciatus from Benin, West Africa. Acta Trop. 2007;101:207-16.

42. Agbohessi TP, Toko II, Kestemont P. État des lieux de la contamination des écosystèmes aquatiques par les pesticides organochlorés dans le Bassin cotonnier béninois. Cahiers Agricultures. 2012;21:46-56.

43. de Souza D, Kelly-Hope L, Lawson B, Wilson M, Boakye D. Environmental factors associated with the distribution of Anopheles gambiae s.s. in Ghana; an important vector of lymphatic filariasis and malaria. PLoS ONE. 2010:5:9927.

44. Assogba BS, Djogbenou L, Saizonou J, Diabaté A, Dabiré RK, Moiroux $\mathrm{N}$, et al. Characterization of swarming and mating behaviour between Anopheles coluzzii and Anopheles melas in a sympatry area of Benin. Acta Trop. 2014;132:53-63.

45. N'Guessan R, Corbel V, Akogbéto M, Rowland M. Reduced Efficacy of Insecticide treated nets and indoor residual spraying for malaria control in pyrethroid resistance area, Benin. Emerg Infect Dis. 2007;13:199-206.

46. Kudom AA. Larval ecology of Anopheles coluzzii in Cape Coast, Ghana: water quality, nature of habitat and implication for larval control. Malar J. 2015;14:447.

47. Gimonneau G, Pombi M, Choisy M, Morand S, Dabiré RK, Simard F. Larval habitat segregation between the molecular forms of the mosquito, Anopheles gambiae in a rice field area of Burkina Faso, West Africa. Med Vet Entomol. 2012;26:9-17.

48. Nkya TE, Akhouayri I, Poupardin R, Batengana B, Mosha F, Magesa S, et al. Insecticide resistance mechanisms associated with different environments in the malaria vector Anopheles gambiae: a case study in Tanzania. Malar J. 2014;13:28.

49. Marcombe S, Mathieu RB, Pocquet N, Riaz MA, Poupardin R, Selior S, et al. Insecticide resistance in the dengue vector Aedes aegypti from Martinique: distribution, mechanisms and relations with environmental factors. PLoS ONE. 2012;7:e30989.

50. Nkya TE, Akhouayri I, Kisinza W, David JP. Impact of environment on mosquito response to pyrethroid insecticides: facts, evidences and prospects. Insect Biochem Mol Biol. 2013;43:407-16.

51. Djouaka RF, Bakare AA, Coulibaly ON, Akogbeto MC, Ranson H, Heming way J, et al. Expression of the cytochrome P450s, CYP6P3 and CYP6M2 are significantly elevated in multiple pyrethroid resistant populations of Anopheles gambiae s.s. from Southern Benin and Nigeria. BMC Genomics. 2008;9:538.

52. Poupardin R, Reynaud S, Strode C, Ranson H, Vontas J, David JP. Cross induction of detoxification genes by environmental xenobiotics and insecticides in the mosquito Aedes aegypti: impact on larval tolerance to chemical insecticides. Insect Biochem Mol Biol. 2008;38:540-51.

53. Poupardin R, Riaz MA, Jones CM, Chandor-Proust A, Reynaud S, David JP. Do pollutants affect insecticide-driven gene selection in mosquitoes? Experimental evidence from transcriptomics. Aquat Toxicol. 2012;114:49-57.

54. Tallaki K. The pest control systems in the market gardens of Lomé, Togo. In: Mougeot LJA, editor. AGROPOLIS: the social, political and environmental dimensions of urban agriculture. London: IDRC, Earthscan; 2005. p. 51-67.

55. Klinkenberg E, McCall P, Wilson MD, Amerasinghe FP, Donnelly MJ. Impact of urban agriculture on malaria vectors in Accra, Ghana. Malar J. 2008;7:151.

56. Keiser J, Utzinger J, Castro MC, Smith TA, Tanner M, Singer BH. Urbanization in sub-Saharan Africa and implication for malaria control. Am J Trop Med Hyg. 2004;71:118-27.

57. Diabaté A, Baldet T, Chandre F, Akogbeto M, Guiguemde T, Darriet F, et al. The role of agricultural use of insecticides in resistance to pyrethroids in Anopheles gambiae s.l. in Burkina Faso. Am J Trop Med Hyg. 2002;67:617-22.

58. Diabaté A, Baldet T, Chandre F, Guiguemde T, Guillet P, Hemingway J, et al. First report of the $\mathrm{kdr}$ mutation in Anopheles gambiae $\mathrm{M}$ form from Burkina Faso, West Africa. Parasitology. 2002;44:157-8.

59. Carnevale P, Robert V, Boudin C, Halna JM, Pazart L-H, Gazin P, et al. La lutte contre le paludisme par les moustiquaires imprégnées de pyréthrinoïdes au Burkina-Faso. Bull Soc Path Exot. 1988;81:832-42.

60. Etang J, Manga L, Chandre F, Guillet P, Fondjo E, Mimpfoundi R, et al. Insecticide susceptibility status of Anopheles gambiae s.l. (Diptera: Culicidae) in the Republic of Cameroon. J Med Entomol. 2003;40:491-7.

61. Dabiré RK, Namountougou M, Diabaté A, Soma DD, Bado J, Toé HK, et al. Distribution and frequency of kdr mutations within Anopheles gambiae s.I. populations and first report of the Ace.1G119S mutation in Anopheles arabiensis from Burkina Faso (West Africa). PLoS ONE. 2014;9:e101484.

62. Nwane P, Etang J, Chouaibou M, Toto JC, Kerah-Hinzoumbé C, Mimpfoundi R, et al. Trends in DDT and pyrethroid resistance in Anopheles gambiae s.s. populations from urban and agro-industrial settings in southern Cameroon. BMC Infect Dis. 2009;9:163.

63. Akogbéto MC, Djouaka RF, Kindé-Gazard DA. Screening of pesticide residues in soil and water samples from agricultural settings. Malar J. 2006;5:22.

64. Abuelmaali SA, Elaagip AH, Basheer MA, Frah EA, Ahmed FT, Elhaj HF, et al. Impacts of agricultural practices on insecticide resistance in the malaria vector Anopheles arabiensis in Khartoum State, Sudan. PLoS ONE. 2013;8:e80549.

65. Touré M, Yapi YG, Carnevale P, Chandre F. Impact of long-lasting insecticidal nets and indoor residual sprayings on the knockdown resistance mutation in Anopheles gambiae s.s. in western Côte d'Ivoire. IJIAS. 2016;15:114-21.

\section{Publisher's Note}

Springer Nature remains neutral with regard to jurisdictional claims in published maps and institutional affiliations.
Ready to submit your research? Choose BMC and benefit from:

- fast, convenient online submission

- thorough peer review by experienced researchers in your field

- rapid publication on acceptance

- support for research data, including large and complex data types

- gold Open Access which fosters wider collaboration and increased citations

- maximum visibility for your research: over $100 \mathrm{M}$ website views per year

At BMC, research is always in progress.

Learn more biomedcentral.com/submissions 